\title{
Tourist Resort Location Using Analytical Hierarchy Process and Its Impact on Tourism (Environmental Ecological Study: Khansar City)
}

\author{
Mohammad Reza Shaghaghipour*, Maryam Larijani" \\ Department of Environmental Education, Payame Noor University (PNU), Tehran, Iran \\ Email:shaghaghi65@gmail.com, larijaniresearch@yahoo.com
}

How to cite this paper: Shaghaghipour, M.R. and Larijani, M. (2017) Tourist Resort Location Using Analytical Hierarchy Process and Its Impact on Tourism (Environmental Ecological Study: Khansar City). Open Journal of Ecology, 7, 365-376. https://doi.org/10.4236/oje.2017.76026

Received: May 27, 2017

Accepted: June 19, 2017

Published: June 22, 2017

Copyright $\odot 2017$ by authors and Scientific Research Publishing Inc. This work is licensed under the Creative Commons Attribution International License (CC BY 4.0). http://creativecommons.org/licenses/by/4.0/

\begin{abstract}
Analytical Hierarchy Process (AHP) is one of the most extensive multi criteria decision making tools. The analytic hierarchy process (AHP) is a structured technique for organizing and analyzing complex decisions, based on mathematics and psychology. The process of locating method (AHP) can be implemented in IDRISI software. The hierarchical levels are objective. The couple of sets have been compared and their weights have been defined. Then, the factor of proportion of agreement was defined. In this study, Khansar city in northwest province is considered. The present study aims at locating tourist resorts' method (AHP), GIS techniques and utilization of the software IDRISI has been done. Criteria such as slope, aspect, hypsometry, geology, land use, soils, distance from places of residence, distance from roads and rivers are considered. The results of this study show that the city has the potential for locating tourist resorts.
\end{abstract}

\section{Keywords}

Ecology, Location, AHP, Khansar City, Tourist Resorts, GIS

\section{Introduction}

Recently, tourism has been taken into consideration in potential distant areas of the world [1]. It has been among communities in different types. It is based on travel and relocation which requires different psychological, cultural, social and financial needs [2].

By 2009, the number of travelers around the world has been 880 . This number is predicted to be 1.6 milliard people in 2020. Due to increase in living standards, people's income, decrease of travel limitation and transportation costs, it's pre-

*Master Student.

\#Assistant Professor. 
dicted that tourism, its role and the number of travelers will increase in the economy of world [3].

Tourism is complicated and varied than before. Today, travelers spend less time in the destinations but they have various travels. They mostly focus on the environment of the destination and expect values more than costs. They also demand more services. Resistance is needed in various financial, social and environmental aspects and in order to have the stability, more planning and management are needed [4]. Since tourism has a bilateral relationship with environment and economic-social activities, it can have negative consequences in these areas. Therefore, firstly, identifying the effects and consequences of tourism and secondly, managing these effects can decrease such negative consequences and they can increase the positive ones.

Tourist resorts are self-contained destinations established by a wide offer of facilitations, tourist services, recreation, education or health. They are planned places in forms of complexes near shores, mountain recreation complexes, ski sites, villas, mineral water resorts, diving and fishing complexes, resting places, complexes near unique natural attractions and complexes near historical areas. However, today, recreation complexes are based on a mixture of attractions and tourist activities. Due to the current procedures of tourism, market's focus on facilitations, educational services and recreation, such issues are necessities in tourism planning and management [5].

\section{Literature}

Regarding AHP, there are various studies focused on GIS and the effect of tourism. Some of them are suggested as follows:

[6] described the application of GIS in determining the proper width for ecotourism of eastern Ontario. They firstly provided a list of resources and required criteria for ecotourism. Then they used GIS techniques to measure rating in various widths based on the model and criteria. Finally, the GIS was used to identify the best potential places.

[7] used GIS to locate proper places for tourism expansion in Lombak island of Malaysia. They identified some potential places for tourism expansion by multiple and mixed evaluation.

[8] conducted a study titled "the use of GIS in ecotourism decision making for African's shell". The GIS was used to zone the national park of Uganda.

[9] studies the proper location of coast areas by using GIS and AHP method. Three regions were selected as proper areas for the coast tourism. They are namely Amir Coast, Labe Darya coast and the eastern coast of Kiashahr.

[10] analyzed Kashan's tourism locations by using GIS. By using Makhdoom's ecological model, it revealed that the north western and eastern of this region had the most potentials for the development of centralized tourism. The central and western regions were found to be proper for widespread tourism (class 1).

[11] tried to locate the tourism villages in a study by using SWOT model and GIS in Kaftar Lake. By merging 23 information layers in GIS setting and by using the SWOT technique, they found that creating a tourism village in southern 
mountains is the best choice. Finally, some guidelines were offered for development of tourism in Kaftar lake.

[12] studied the role of GIS in analyzing the tourism arena. Based on the information layers and GIS, they recognized that $24.47 \%$ of all Toyserkan city has the potential of doing tourism activity for Bolin region.

[13] studied the efficiency of hierarchical analysis method in flood-producing studies. The information layers were used by AHP model and finally the flood producing zoning of Khazar had higher dangers in northern areas.

[14] studies the ecosystem activities in terms of ecologic in north Zagros woods. In order to decrease the decays and to increase the resistance, the ecologic capability of the region were evaluated for the developed ecosystem by multi-criterion analysis and GIS. The ecological criteria and sub-criteria affect the ecotourism were selected and their weight was obtained by using the hierarchical analysis.

[15] studied the feasibility of recreation complexes in Mazandaran city and its influence on Amol tourism with the approach of relationship between tourism and architecture. The results indicate that the systemic planning and the implementation of comprehensive tourism plans leads to the development of city, attracting the traveler and creating a peaceful environment away from everyday tensions.

[2] analyzed a proper zoning of ecosystem in Zanjan city by using GIS. In the present research, proper zoning of ecotourism activities were analyzed and the information layers were provided. The proper zoning was also revealed by overlap of layers. The results show that more than $30 \%$ of the province's width has the potential for ecotourism activities.

[3] studies the spatial distribution and location of Babolsar parks by using fuzzy logic and FAHP. The results show that the distribution of Babolsar parks is inappropriate. The No. 6 magazine has the most priorities for creating the greenbelt.

In the present research, all resources are changed to map so that they have the capability of AHP model for the region. The final weight of overlap has been done after using the model and the proper locations were recognized for creating tourism resorts. Moreover, environmental, economic and social effects and consequences have been analyzed.

\section{Data and Method}

The existence of different criteria in selecting a suitable place makes the multi-criteria decision analysis methods necessary. AHP is the most prevalent method. The criteria such as slope, aspect, hypsometric, geology, land use, soils, distance from places of residence, distance from roads and rivers are weighted for creating tourism resorts by using AHP model and they are mixed in GIS to recognize proper places for creating tourism resorts. An accident is the result of interaction of some factors and its evaluation is impossible. Therefore, for modeling the phenomena, the main and influential factors should be identified. 
Moreover, after identifying each criterion, they should gain special weight based on their relative importance and effect [6].

In fact, AHP is a comprehensive method for solving multi-criteria decisions [5]. AHP is used in solving the problems of strategic decision [4]. AHP is established by [11]. The basic of this method is based on paired comparison and the ratio of element priority on each other in relation of the suggested criteria. It's used in order to solve the multi-criteria evaluation problems and to determine the multi-alternation priority [3]. Locating and determination of a proper place is regarded as the spatial decision making subjects. The location is the center of conscious activity [12]. The increase of demand for occupying a special place is led by human's conscious performance which causes increase in competition among humans and firms for establishing in a given place. The development of capitalism and approaching locations with the perspective of economics, the competition were taken into consideration for selecting the best place as the main goal of economic activities (Shekooyi, 279-281). A proper place for an activity requires some factors. There are various factors that can affect the decisions regarding the location [13].

\section{Location}

Khansar is placed on 33 degree and 13 minutes of north. It's also placed on 50 degree of geographical length and 19 minutes of east. It's a little far from Iran's central desert and it's located in $150 \mathrm{~km}$ of northwestward in Isfahan. It's bounded from north to Golpayegan, from east to Tiran, Kron and Najafabad and from south to Fereydoon. It's located in the central place of Iran and Zagros mountains (Khansar mountain) with $900 \mathrm{~km}$ width. Khansar has a clement weather. It is located 2250 meter above sea level and the vegetation includes walnut, cedar, fruit trees such as plum, apple and various gardens along with farmlands, red tulip and their famous Fritillaria. In Khansar, the highest degree is $31 \mathrm{C}$. in summer. The average of temperature is $31 \mathrm{C}$. in this month. In spring, the weather is mild and the trees have blossom. In fall, the nature is beautiful due to the colorful quality. In winter, the cold weather is along with a mass snow. In cold seasons, the temperature decreases under 20 or below 0 degree. In the warmest days of summer, the weather increases to $38 \mathrm{C}$. The relative humidity is $2.32 \mathrm{C}$ [14]. (Figure $1 \&$ Figure 2).

\section{Tourism impacts}

Due to the nature of tourism activity and its interaction with different economic-social activities, their impacts can be variable. Specially, it seriously affects the local environment and the host community. The social impact of tourism can be both negative and positive. In the developed tourism locations, the positive and social impacts of tourism in local communities include: self-sufficiency and empowering the local economy, admiring the local community and their culture, investing on tourism in cultural resource, supporting the cultural tradition, increase of understanding among cultures especially through music, local crafts, lifestyle, housing and other experiences. The negative impacts of tourism on local community includes deprivation of some welfare benefits for 


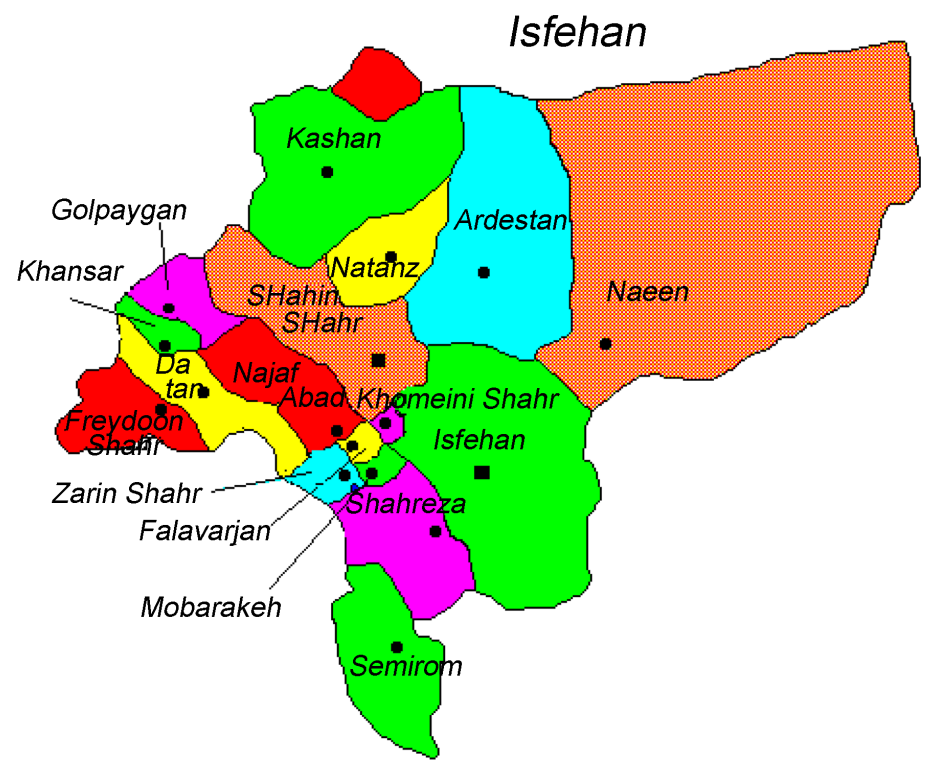

Figure 1. The location of Isfahan and Khansar city.

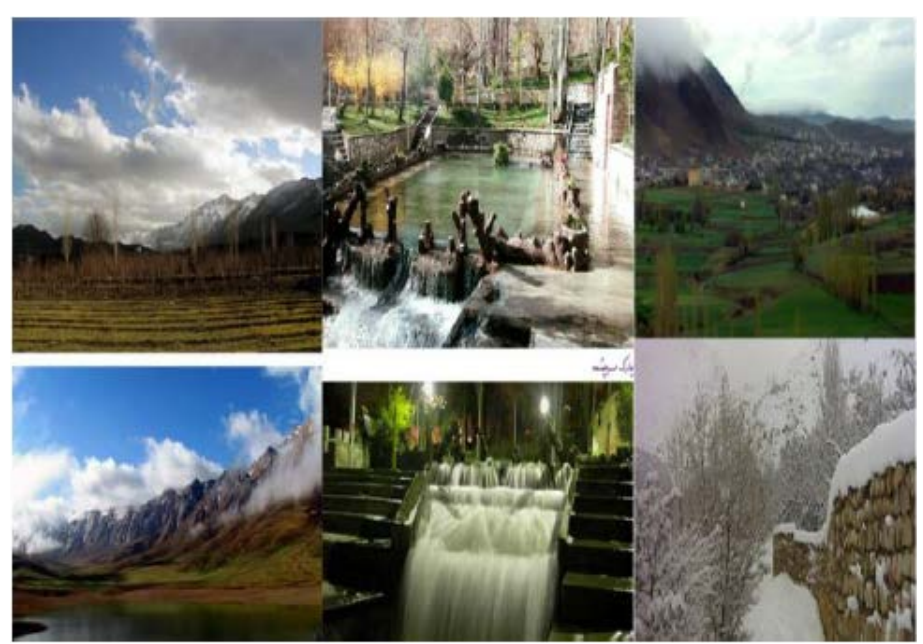

Figure 2. A photo of Khansar.

the host community, more demands for the rare resources such as water, dependency of the host locals to tourism, misbehavior and the lack of cultural sensitivity toward tourism. Locating the tourist resorts had various impacts on the locating areas including designing the secure and safe areas away from city, absorbing tourists to these areas, using the facilities, investing and competing with tourism firms, employment and revenue generating. On the other hands, it destroyed the visual beauty of tourism resorts and caused pollution. Therefore, the feasibility and locating the tourism resorts can be done by considering some issues, creating balance between demands and importantly, by exact planning and management and considering the influential factors.

\section{Findings}

Using the AHP along with GIS for locating the tourist resorts involve some phases. After identifying and preparing all effective criteria and factors in select- 
ing the best location, it's necessary to prepare maps of the required layers and to process and weight the information layers. Some layers need to be changed in GIS setting (such as changing the structuring to raster structure, mixing some layers into a layer, providing a map and classifying the layers). In order to do that, some layer maps are provided and weighted:

\section{Slope}

In order to create the slope layer, the location's DEM should be provided. The location of slope layer can be created by using such layer (Figure 3).

\section{Aspect}

The aspect is considered desirability because the location can have certain favors in that location. Since, the aspect is important in the receiving sun glow on foothill, it's significant in study-based planning and projects (Fazelnia et al., 2012, p. 66) (Figure 4).

\section{Hypsometric}

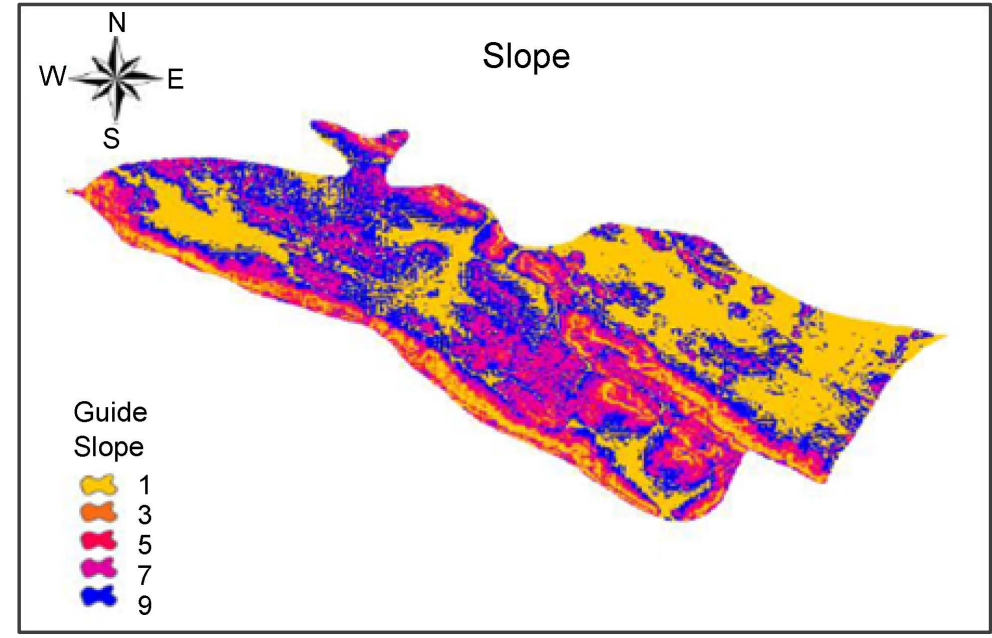

Figure 3. The slope map.

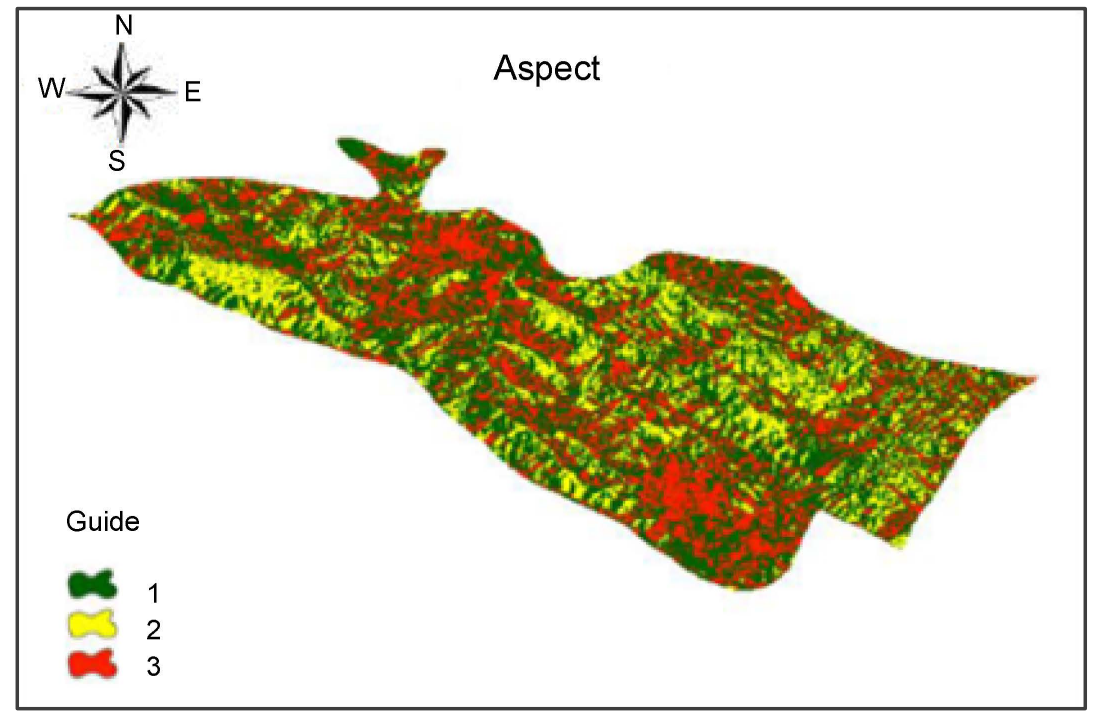

Figure 4. The aspect map. 
The third criterion is related to the hypsometric in location. Since, it cannot be done in every location, thus, based on topography studies, it's clear that how maximum and minimum of hypsometry is distributed and since hypsometric is a relational phenomenon, it's different from one position to the other. Therefore, the decisions are made based on the hypsometric maximum and minimum of the location. Based on the experiences about the city and hypsometric, it can be recognized that which location has the best symmetry in it. Since the hypsometric is a relational phenomenon, it cannot be said that 0 to 100 or 200 to 1200 is the best hypsometric. It's because, that location might not have any hypsometric. Based on the DEM of the location, the minimum and maximum of the hypsometric are respectively 1974 and 3468 (Figure 5).

\section{Geology}

Another parameter is geology. The suggestions of experts should be used and the data weights should be used based on expert's advice. In a geology plan, some zoning might not have the development capability from the perspective of geologist. On the contrary, some locations might have a good geological symmetry. Since the AHP is a multi-criteria issue, the expert's suggestions are necessary for different layers (Figure 6).

\section{Land use and soils}

This item can be used as zoning for producing the land use and soils in terms of agricultural capability. Due to the land use law, the development should not be done in the lands that have a high soil capability. Waste lands or dry farms are lawfully proper locations for the development (Figure 7 \& Figure 8).

\section{Distance from the places of residence}

Maps made of distance analysis methods are in forms of continuous maps and their discretization should be weighted based on the defined zoning of the user and applying weights to the considered layers should be based on AHP (Figures 9-11).

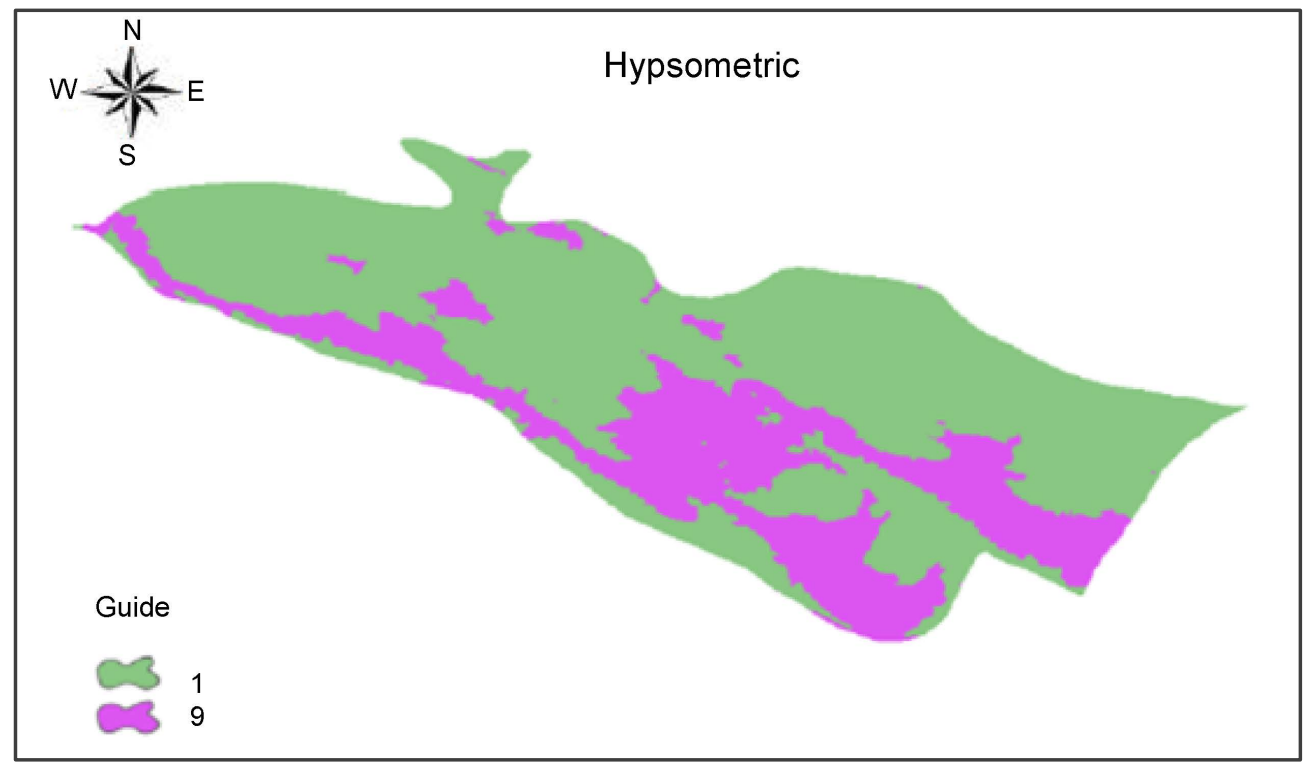

Figure 5. The hypsometric map. 


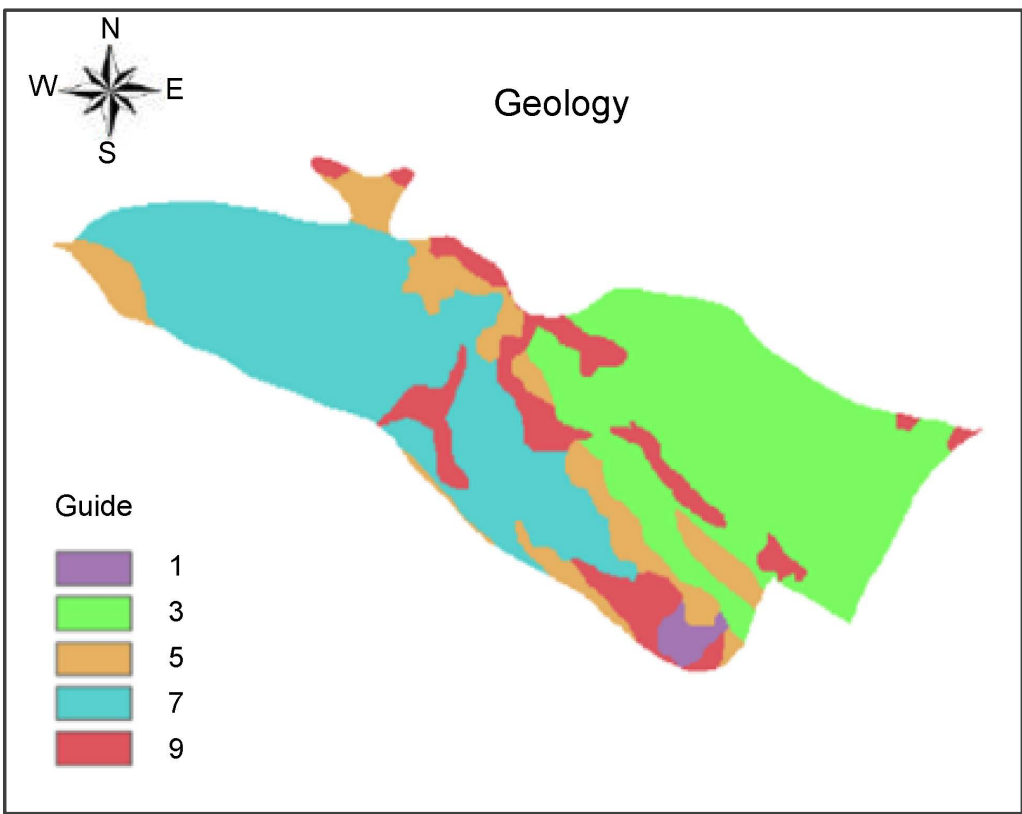

Figure 6. The geology map.

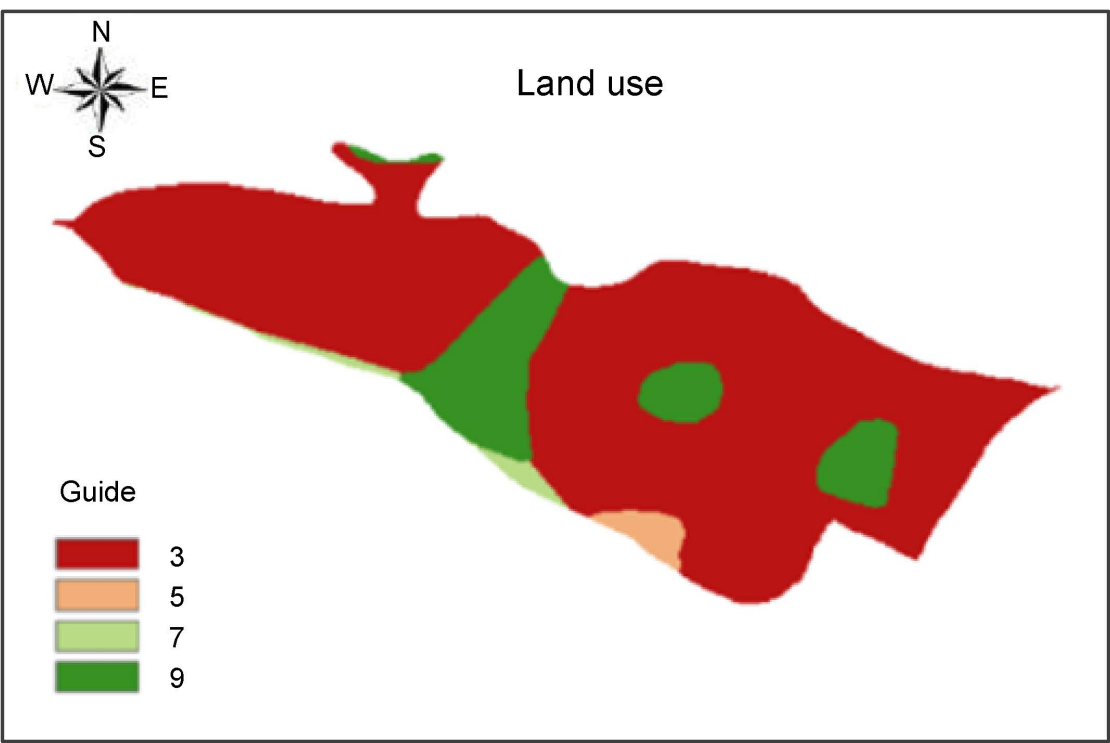

Figure 7. The land use map.

After providing the required maps, the information layers were classified in terms of their effectiveness on resort locating. Then, they were weighted and scored by AHP model. The contingency coefficient value was obtained as 0.05 by using IDRISI software. Therefore it has the required consistency among criteria and matrix of couple comparison. Thus, assuredly, it can be said that these weights can be used in decision making. Finally, we use the Weighted Overlay command to overlap the layers. It gives us a map as an output which shows the final map prioritization and the effect of weights in selecting a proper location. It identifies locations with weak, average and best potentials for creating the tourist resorts (Table $1 \&$ Figure 12). 


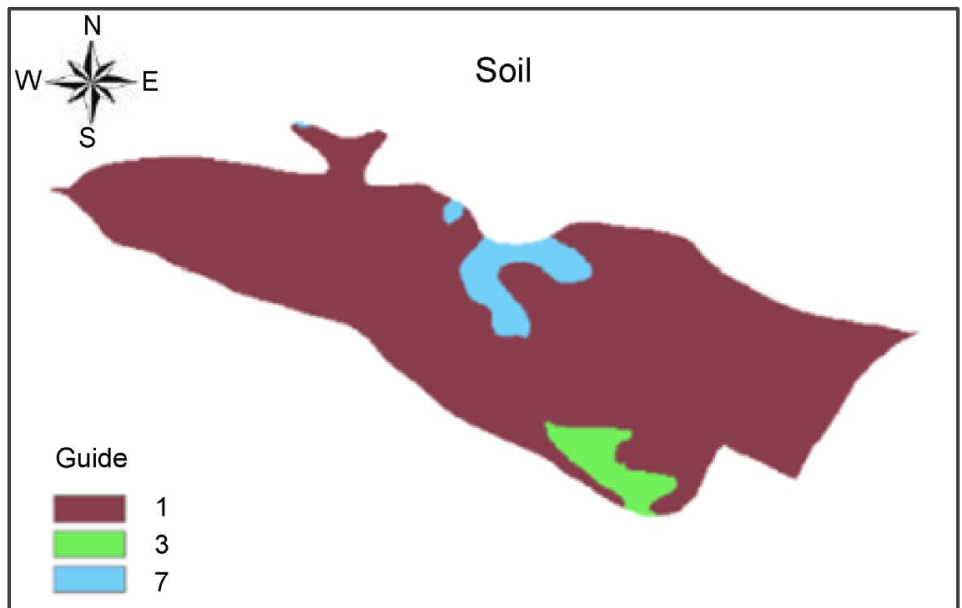

Figure 8. Soil map.

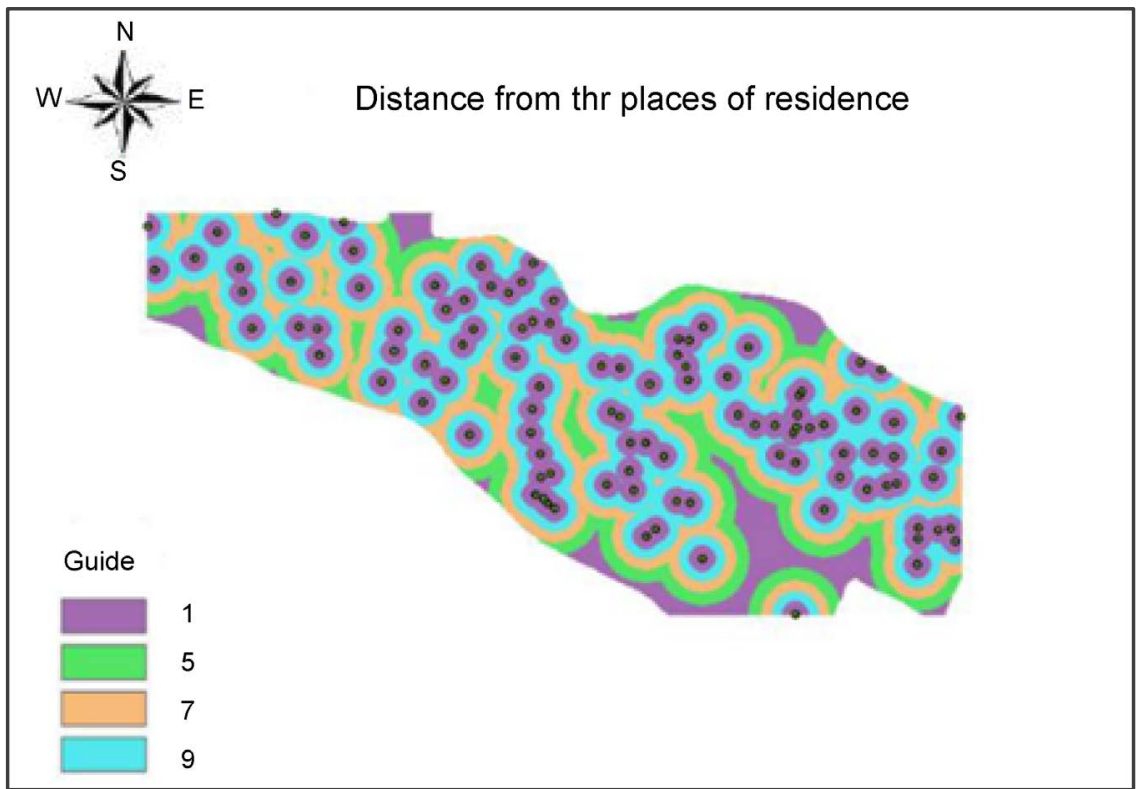

Figure 9. Distance from the places of residence map.

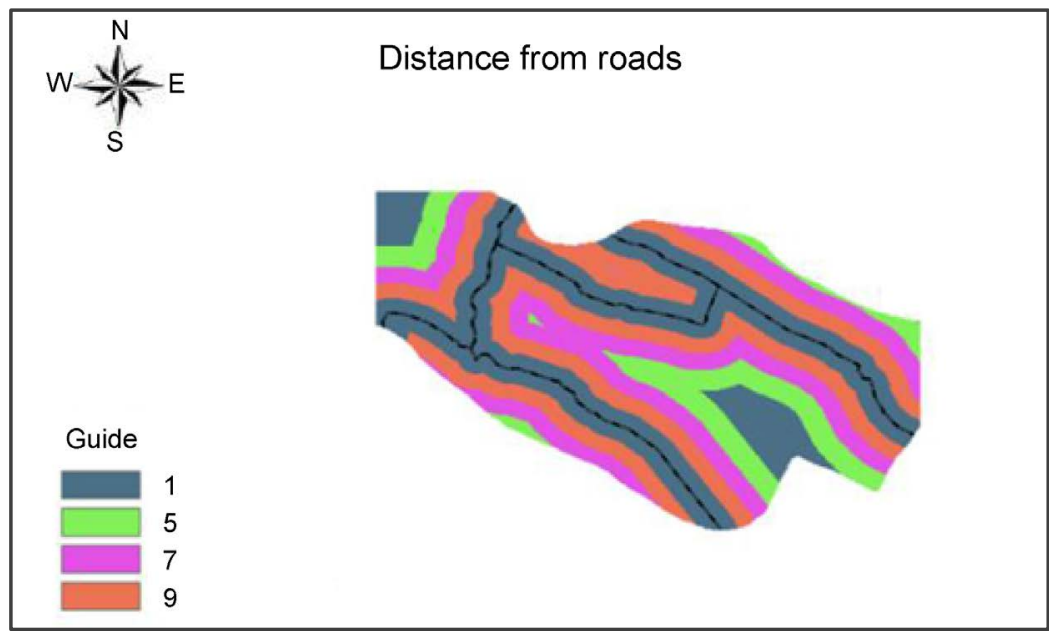

Figure 10. Distance from roads. 


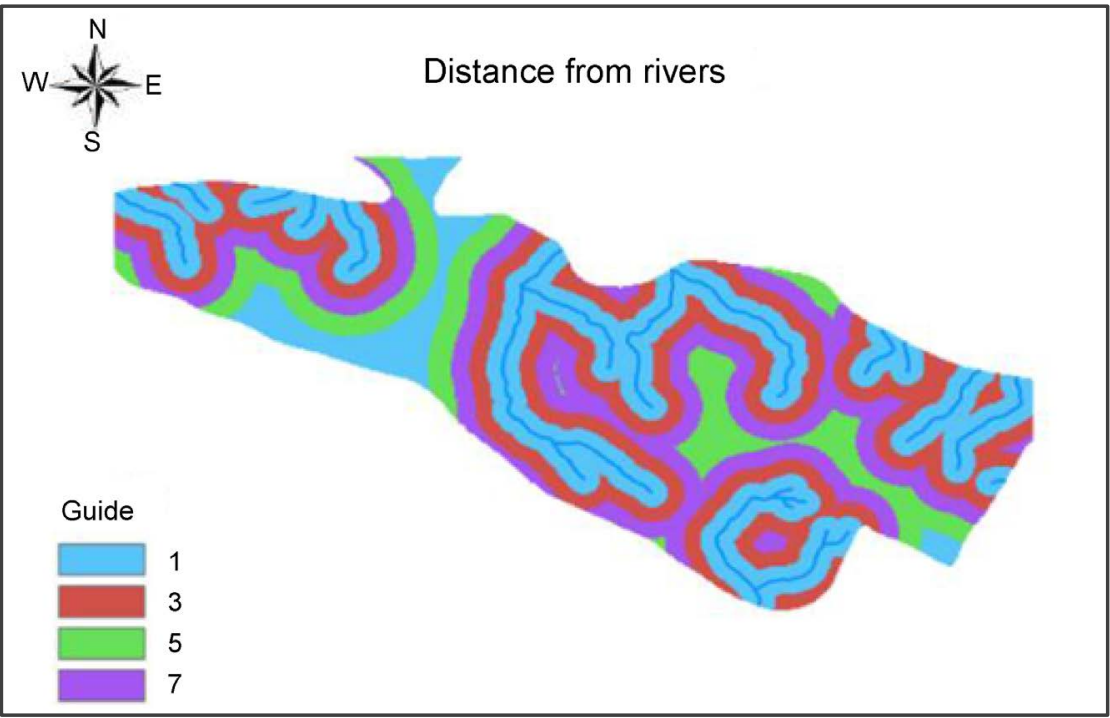

Figure 11. Distance from rivers.

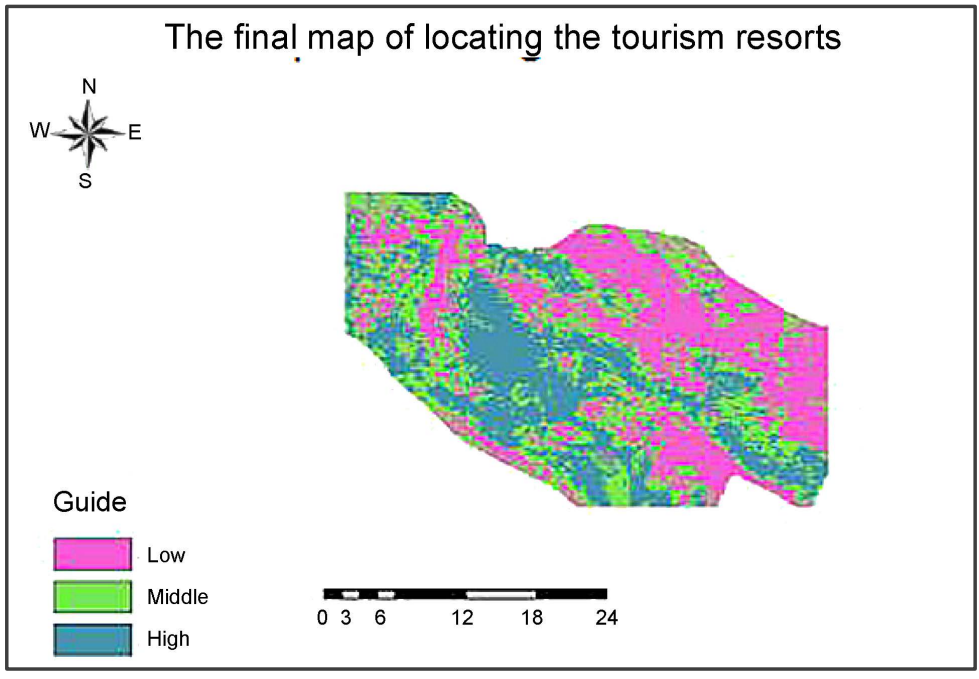

Figure 12. The final map of locating the tourism resorts.

Table 1. Comparing couple of sets useful for locating tourism resorts.

\begin{tabular}{|c|c|c|c|c|c|c|c|c|c|c|}
\hline & $\begin{array}{l}\text { Distance from } \\
\text { rivers }\end{array}$ & $\begin{array}{l}\text { Distance from } \\
\text { roads }\end{array}$ & $\begin{array}{c}\text { Distance from places } \\
\text { of resorts }\end{array}$ & Soil & $\begin{array}{l}\text { Land } \\
\text { use }\end{array}$ & Geology & hypsometric & Aspect & Slope & $\begin{array}{c}\text { Final } \\
\text { weight }\end{array}$ \\
\hline River & 1 & 2 & 3 & 4 & 5 & 6 & 7 & 8 & 9 & 4 \\
\hline Road & 0.5 & 1 & 2 & 3 & 4 & 5 & 6 & 7 & 8 & 7 \\
\hline Places of residence & 0.33 & 0.5 & 1 & 2 & 3 & 4 & 5 & 6 & 7 & 8 \\
\hline Soil & 0.25 & 0.33 & 0.5 & 1 & 2 & 3 & 4 & 5 & 6 & 9 \\
\hline Land use & 0.2 & 0.25 & 0.33 & 0.5 & 1 & 2 & 3 & 4 & 5 & 10 \\
\hline Geology & 0.16 & 0.2 & 0.25 & 0.33 & 0.5 & 1 & 2 & 3 & 4 & 12 \\
\hline hypsometric & 0.14 & 0.16 & 0.2 & 0.25 & 0.33 & 0.5 & 1 & 2 & 3 & 15 \\
\hline Aspect & 0.12 & 0.14 & 0.16 & 0.2 & 0.25 & 0.33 & 0.5 & 1 & 2 & 17 \\
\hline \multirow[t]{2}{*}{ Slope } & 0.11 & 0.12 & 0.14 & 0.16 & 0.2 & 0.25 & 0.33 & 0.5 & 1 & 18 \\
\hline & & & & & & & & & & 100 \\
\hline
\end{tabular}

Source: Authors' findings. 


\section{Discussion}

One of the most important findings of the present research is the focus on tourist's awareness toward the attraction of these locations. Based on the experiences and the studies done in this area, it's revealed that using incorporated methods (virtual and non-virtual) such as leaflet, posters, education websites, advertising SMS by mobile, social networks, creating ports and systems for education for these locations can be influential. It's also necessary for the managers to seriously create and develop these incorporated methods.

\section{Conclusion}

The analyses of the results show that AHP along with ArcGis can be used as powerful instrument for involving various criteria in tourist resort locating. The present research incorporated 9 information layers in GIS setting for creating the best tourism resorts of Khansar city. This city has the potential for locating the tourist resorts. Khansar has many benefits and statuses for tourism due to these potentials. However, these opportunities have not been introduced correctly in the last year and there's no planning for that. The activities are limited to identification and maintenance of some historical buildings. There should be a comprehensive planning and structure for developing tourism in Khansar. Some of them are suggested as follows: Holding festivals, seminars, traditional ceremonies, markets, making villages embellish, identifying zoning with village values, educating and awareness raising the tourists by using incorporated methods (virtual and non-virtual) such as leaflet, posters, education websites, advertising SMS by mobile, social networks, creating ports and systems and other awareness raising methods. Moreover, informing tourists about these facilities, investing on rebuilding the natural attraction, avoiding the excess land use by civic development, applying the guideline plan for tourism enhancement, implementing a management system, using the evaluation as a tool for improving the management procedures and focusing on awareness raising and educating through incorporated methods (virtual and non-virtual) should be taken into consideration.

\section{References}

[1] Ebrahimi Fini, F. (2008) Analyzing the Locations Suitable for Kashan's Natural Tourism by Using GIS Software. Journal of Biome and Plants, 15, 78-86.

[2] Sani, N., et al. (2011) Analyzing the Ecotourism Activities in Case of Ecology for Northern Zagros Woods Using Multi-Criteria Decision Making, GIS and Remote Sensing. Amayesh Sarzamin, 4, 47-53.

[3] Jamshidi, H. and Solmi, S. (2012) Feasibility Study of Recreation and Service Complexes in Mazandaran Province and Their Effectiveness on Amol City with the Approach of the Interaction between Tourism and Architecture. Proceedings of the First National Conference of Tourism, Hamedan, 17 March 2012.

[4] Daghestani, S. (2012) Tourism Attraction, Concepts of Management and Planning. Mahkameh, Tehran.

[5] Iran and World Tourism Organization (2002) The Role of Village Tourism in Is 
Development. Journal of Modarres (Human Science), 2, 23-40.

[6] Tourism Area Organization. http://www.tao.ir/

[7] Isfahan's Tourism, Craft and Cultural Heritage Organization (2012).

[8] Shekooyi, H. (1996) Novel Thinking in Geographical Philosophy. Gitashenasi Press, Tehran.

[9] Abdi, Kh. (2006) Locating and Modeling the Civic Greenbelt Transmittancy (Park in Scale of Sector), Case Study: Region 1 of Sanandaj. Master's Thesis, Tabriz University, Tabriz.

[10] Fazelnia, G.H., Hakimdoost, H. and Belyani, Y. (2012) Comprehensive Guideline of GIS Practical Models in Civic, Village and Environmental Planning. Azadpeyma Press, Tehran.

[11] Karimpanah, R. (2005) Ecotourism Analysis and Its Role in Development of Kordestan Province. Master's Thesis, Tarbiat Modarres University, Tehran.

[12] Kiomarsi, H., Taghvayi, M. and Taghizadeh, M. (2011) Locating the Tourism Villages by Using GIS and SWOT Model (Case Study: Coast of Kaftar Lake). Journal of Geography and Environmental Planning, 42, 99-120.

[13] Karimi, J. and Mahboobfar, M. (2011) The Use of Climate in Developing the Tourism Industry. Arkane Danesh Press, 184.

[14] Iran's Statistics Center (2011) Journal of Iran's Statistics in Year 2011. Iran's Statistics Center.

[15] Moghadas, M., Vahidian, F. and Vahidian, A. (2005) The Hierarchical Evaluation and Presenting a Method for Ordering the Fuzzy Numbers. Proceedings of the Fourth National Conference of Tehran's Industry Engineering, Tehran, 62-69.

Submit or recommend next manuscript to SCIRP and we will provide best service for you:

Accepting pre-submission inquiries through Email, Facebook, LinkedIn, Twitter, etc. A wide selection of journals (inclusive of 9 subjects, more than 200 journals)

Providing 24-hour high-quality service

User-friendly online submission system

Fair and swift peer-review system

Efficient typesetting and proofreading procedure

Display of the result of downloads and visits, as well as the number of cited articles

Maximum dissemination of your research work

Submit your manuscript at: http://papersubmission.scirp.org/

Or contact oje@scirp.org 